\title{
SETS-BASED GUIDED EXPERIMENT BOOK: EMPOWERING SCIENCE PROCESS SKILLS OF ELEMENTARY SCHOOL STUDENTS
}

\author{
Pinkan Amita Tri Prasasti* and Ivayuni Listiani \\ Primary School Teacher Education Study Program, Faculty of Treacher Training and Education, \\ Universitas PGRI Madiun, Madiun, East Java, Indonesia \\ *Corresponding email: pinkan.amita@unipma.ac.id
}

\begin{abstract}
In this $21^{\text {st }}$-century, students are expected to have current competencies in which one of them is science process skills. The aim of this research was to empower science process skills through the SETS-based guided experiment book. This Posttest Only Control Group Design study involved 50 students of fifth grade which divided into two groups i.e. 25 students as the experimental group and 25 students as the control group. The activities were carried out for three months outside of school. The empowerment of science process skills was measured from the increasing scores before and after the implementation of the SETS Guided Experiment Book. The results showed that there was a significant different between experimental group and control group as the significancy value was 0.000 (sig. $<0.05$ ). This means that the SETS-based guided experiment book can empower Science process skill of elementary school students.
\end{abstract}

Keywords: Guided experiment book, SETS, science process skill

(C) 2018 Department of Biology Education, FTTE, University of Muhammadiyah Malang, Indonesia

\section{INTRODUCTION}

The proliferation of scientific knowledge has been enabling learners to improve their competences in understanding the problems faced by modern society which highly dependent on technology (Kalolo, 2014). Along with the domination of globalization in almost all aspects; economics, politics, social life, culture values transfer, as well as education; this era been bringing challenges for nowadays generations to deal with it (Goryakin, Lobstein, James, \& Suhrcke, 2015; Jonnalagedda, 2011). Thus, in turn, bears a certain context for school curriculums in general as significant as science learning (Blankenburg, Höffler, \& Parchmann, 2016; Durib, 2014; Martín, Pozo, Mateos, Martín, \& del Puy Pérez Echeverria, 2014). Consequently, schools and the all attributes are 'forced' to be ready to provide the most proper education circumstances which enable the learners to optimize their higher order thinking skills to face complex issues surround them (Husamah, Fatmawati, \& Setyawan, 2018).

In 2015, PISA (Programme for International Student Assessment) reported that Indonesian science literacy did not meet satisfactory results. Indonesian students has been considered to have low understanding of basic concept. It was found that more than $50 \%$ of the students $(61.6 \%)$ had very limited scientific knowledge (below level 1). While the remaining percentage was divided into level 2 (able to do simple research), level 3 (able to identify scientific problems), level 4 (are able to utilize science for life), and level 5 i.e. $27.5 \%, 9.5 \%$, and $1.4 \%$ respectively. The worst condition was there was no student mastering in the fift and sixth levels.

Scientific literacy empowerment can be done through the process of learning skills (Holbrook \& Rannikmae, 2009). The process of learning skills is directed to set formation of the Science Process Skills (SPS) i.e. performance skill. SPS contains of two aspects namely cognitive skill as the basic knowledge in mastering SPS and skills of sensorimotor. SPS is the key point of the scientific literacy development through an applied process (Prasasti, 2017). Scientific literacy means being able to apply the concepts, obtained in school, to the natural phenomena occur in everyday life (Chiappetta \& Koballa, 2010; Hobson, 2012).

The nature of learning science is not enough to merely remember and understand the concepts discovered by scientists. However, the 
most important point is the habituation of the scientists behavior in finding the concepts that are carried out through experiments/practicum and scientific researches. Ergul et al. (2011) stated that the process of concepts discovery involves fundamental skills through scientific experiments can be carried out and improved through practical activities in the laboratory. The main purpose of the practicum is to train students to work according to scientific procedures in order to obtain scientific knowledge, skills and values.

Practicum activities or experiments become mandatory in teaching science (Dimopoulos, Paraskevopoulos, \& Pantis, 2009), with this activity, students are expected to be: 1) able to learn science through direct observation of symptoms and scientific processes 2) able to practice scientific thinking skills, 3) able to instill and develop scientific attitudes, 4) able to find and solve new problems through scientific methods and so forth. The results of the survey and need analysis in the field conducted in 12 primary schools in Madiun City showed that the average of learning outcomes was of 7.26; meanwhile, the learning process carried out by teachers was $78 \%$ led to minds-on learning and only $22 \%$ led to hands-on data routines. The experimental activities in science learning were carried out one to three times in each semester. Ideally, the experimental activities carried out on each Basic Competence (or Kompetensi Dasar/KD) which are adjusted to the characteristics of the learning material.

The other survey results related to student interest in practical activities were inversely proportional to 210 elementary school students, almost 95\% liked practicum activities and were very enthusiastic about the activity. This shows the gap which needs to be examined if the student interest in practical activities is very good. One of the vital practical facility is a practicum guide (Bigbee, Curtiss, Litwin, \& Harkin, 2010). The practical guide aims to help and guide students' activities so that they can work in a directed manner and as a reference for the stages of practical work for students as well as for the teachers. Besides that, guided experiment helps students to understand the practicum materials.

One of the alternative approach aimed to cultivate students' understanding is SETS (Science, Environment, Technology, and Society). This approach integrates science and technology by considering human and environmental system in teaching and learning process. Thus, the students' learning outcome resulted by this spproach is expected to be able to develop themselves as an individual and as a part of society.

The results of the feasibility of SETS-based guided experiments book products were carried out through the initial field testing phase, which included a series of expert and practitioner validation tests consisting of expert presentation of learning books, validation of science experts, and expert validation in term of its readability.

SETS-based guided experiment book approach is expected to have a positive impact. According to Yörük, Morgil, and Seçken (2010), the experimental guide book is addressed for some goals: (1) students are accustomed to having a comprehensive mindset in viewing science that is integrated with the environment, technology, and society; (2) SETS will inform students that technology affects the science growth rate, as well as its impact on the environment and society; (3) students are expected to be able to unite the concepts of science that are found through the activities of science process skills, namely practicum activities, and apply the concept based on the environment and technology so that it can be widely used by the community.

\section{METHOD}

This research was conducted at Sekolah Dasar Negeri (SDN) or State Elementary School (SES) 01 of Manisrejo, Madiun, at the East Java Province, Academic Year 2018-2019. The research design used was Posttest Only Control Group Design. It was comprised of two groups: the experimental group, which was treated with the use of SETS-based guided experiment book, and the control group, which was treated with the lecture and discussion methods. The population in the study were all elementary school students in grade V SES at the Madiun, Academic Year 2018-2019 with 106 students. The sampling technique was cluster random sampling. As many as 25 students of class VA were the Control Group (CG) and 25 students of class VB as the Experiment Group (EG).

Data collection techniques used were test, documentation, observation, interview and questionnaire. The data were obtained from the results of scientific literacy and students' cognitive learning outcome. Meanwhile, the 
Prasasti \& Listiani / JPBI (Jurnal Pendidikan Biologi Indonesia) / 4 (3) (2018) pp. 257-262

documentation was obtained from preliminary studies, needs analysis and at the time of the research activities, the observation was used for needs analysis and field-testing addition, the interview and questionnaire were used at the time of needs analysis. The data obtained was analyszed using independent sample t-test, which was aided using SPSS 21 with the significance level of $5 \%$.

\section{RESULTS AND DISCUSSION}

The results of the SETS-based guided experiment book approach in empowering SPS can be seen in Table 1. Based on the results (Table 1), it can be seen that the CG has a lower mean value on the posttest result (73.72) compared to EG (81.72). This, generally, proves that the use of the book developed has given positive trand in students' understanding in which marked by the score they achieved. Even though it still need to be tested by using $t$ test to determine whether the improvement is significant or not.
Table 1. SPS description data

\begin{tabular}{lllll}
\hline \multirow{2}{*}{$\begin{array}{c}\text { Statistic } \\
\text { Results }\end{array}$} & \multicolumn{2}{c}{ CG } & \multicolumn{2}{c}{ EG } \\
\cline { 2 - 5 } & Pretest & Posttest & Pretest & Posttest \\
\hline Mean & 60.56 & 73.72 & 61.26 & 81.72 \\
SD & 10.266 & 8.860 & 11.231 & 6.64 \\
Variance & 105.39 & 103.50 & 101.21 & 82.50 \\
Minimum & 52.00 & 56.00 & 56.00 & 74.00 \\
Maximum & 80.00 & 80.00 & 82.00 & 98.00 \\
Median & 60.00 & 72.00 & 62.00 & 85.00 \\
N & 25 & 25 & 25 & 25 \\
\hline
\end{tabular}

The results (Table 2) show that there was a significant difference between Class A and Class B. The test used was t-test for two independent groups, namely class A and class $\mathrm{B}$. The results showed that the significance value was 0.000 . In the other words, there was a significance different of SPS between students who were taught by using SETS-based guided experiment book they who were taught without the book mentioned (CG).

Table 2. SPS test analysis results

\begin{tabular}{|c|c|c|c|c|c|c|c|c|}
\hline & & \multicolumn{7}{|c|}{ t-test for Equality of Means } \\
\hline & & \multicolumn{7}{|c|}{ 95\% Confidence Interval of the Difference } \\
\hline & & $\mathbf{t}$ & Df & $\begin{array}{l}\text { Sig. (2- } \\
\text { tailed) }\end{array}$ & $\begin{array}{c}\text { Mean } \\
\text { Difference }\end{array}$ & $\begin{array}{l}\text { Std. Error } \\
\text { Difference }\end{array}$ & Lower & Upper \\
\hline \multirow[t]{2}{*}{ Prestasi } & Equal variances assumed & -3.121 & 82 & .000 & -8.405 & 2.614 & -6.605 & 3.795 \\
\hline & Equal variances not assumed & -3.121 & 81.963 & .000 & -8.405 & 2.614 & -6.605 & 3.795 \\
\hline
\end{tabular}

The highest achievement obtained from the application of SETS-based guided experiment book was that it has provided training for students to experiencing scientific process. The book helped the students in emphasizing the application of science so that the students' interests in science were explored. Moreover, the concept application encompassed by students helps them to work in scientific method frame, which means that their scientific literacy were also improved in the same time.

Septiani and Rustaman (2017) stated that the aspects covered by SPS are observing, interpreting, classifying, predicting, formulating problems, making hypothesis, asking questions, planning experiments, using tools and materials, communicating the results of the experiment and applying the concept. Some of these aspects become the indicators, which were used as references in constructing questions in SPS tests. The main SPS test contains a number of information, which can be in form of table or the students must process graphs. This type of question guides the students to think sistematicly and held their endeavour to analyse as serious as to interpret the data served and making conclusion in the right manner.

In the other words, SPS is developed through practicum activities. Practicum is one of the best means for developing SPS, because in practicum students are trained to develop all of their senses. Ergul et al. (2011) found that inquiry-based teaching plays its role as an enhancer for students' science process skills. Learning science requires experimental activities, which led students to have the better understanding about the concepts they are learning. This activity enables the students to share their ideas with the class members during discussion process as possible as to fulfil the gaps may arise. Thus, they will also learn to build a productive networking with their friends as well as creat a good competition circumtances, which plays as enhancer to optimize the all potentials they have. 
The investigation process as part of SETS stages which related to SPS is considered an open process which let students have their own questions and seek the answers themselves (Durmaz \& Mutlu, 2017; Özgelen, 2012). Gradually, student groups communicate more effectively and enhance their ability to reason and solve task-based problems together (Ismaili, 2000; J. Brame \& Biel, 2015; O’Daniel \& Rosenstein, 2008).

Learning directs students to deal with problems that need to be tested through experimental activities. Trained students think like scientists benefits them to sharpen their skills in determining concepts through systematic activities such as formulating problems, hypothesizing, designing experiments, implementing the design they made in lab, and trying to be able to communicate their research results as the solution for the problems found. The learning activities will naturally lead students to be more accustomed and skilled in science processing so that SPS has optimized students' score in experimental class compare to the control class. Thus, elarning process will be more effective (Artayasa, Susilo, Lestari, \& Indriwati, 2017). By aided with the use of SETS-based guided experiments book, students were invited to be more active in developing hands on activities as considerable as optimize their thinking skills in utilizing tools and materials.

By considering many aspects must be integrated in SETS, the teachers are also required to have a good comprehension of the approach. They must possess broaden and deep knowledge so that they will be able to decide the way to bridging many concepts in term of science, environment, technology, and society. The better the understanding possessed by teachers, the more creative and innovative teaching method served in the classroom (Fiksl, Flogie, \& Aberšek, 2017) as well as in conducting the assessment used such as performance assessment (Septiani \& Rustaman, 2017) to measure the students' achievement. As the students are educated to be care to their environment, to have a high ability in sensing the environmental phenomena is a must for teachers. Thus, teachers and students have the same beliefs that science and technology contribute in the environment changes (Hoferichter, Raufelder, \& Eid, 2015; Oscarsson, Jidesjö, Strömdahl, \& Karlsson, 2012).
In addition, the proliferation of technology advancement must also be mastered by teachers (Brooks-Young, 2007) to serve the students' well as well as managing the learning activities (Pukdeewut, Chantarasombat, \& Satapornwong, 2013). Therefore, teachers must be active in gaining the most up-to-date knowledge not only in their core science field, but also in technology utilization.

Moreover, to implement SETS approach in teaching and learning, the school must also facilitate the program. The school system must be set as compatible as possible to support learning process as the approach obligs adequate facilities and time. The necessity of technology can be presented in form of computerization, internet access, and so forth.

In addition, a good environment can be formed in gardening, a small green house, and so on. It can be more interesting as the school environment is designed to meet SETS application such as the digitalization of the all database of sources related to the all species planted in school garden. Thus, not only the do the teachers can access the materials, but the students as well as school's gardeners are able to access it. This will make the learning environment more interesting which, in turn, motivates the students to be engaged in learning through enunciating the stimulating surrounding around them.

\section{CONCLUSION}

The results of this study showed that there was a significant difference between SPS in CG and EG. The average yield obtained by IG shows an increase. In contrast, there was no significant changes between pretest and posttest scores of CG. This proves that the use of SETSbased experimental guide book is effective in empowering SPS.

It is suggested that before using the SETSbased guided experiment book, the teacher must have a good understanding of the book and look for references about the implementation of the SETS model so that learning can be effectively conducted.

\section{ACKNOWLEDGMENT}

Our thanks are conveyed to PGRI Madiun University as an affiliation and protector of the research team. Our high gratitudes are also addressed to the principals, teachers, and 
Prasasti \& Listiani / JPBI (Jurnal Pendidikan Biologi Indonesia) / 4 (3) (2018) pp. 257-262

students of the research partners for their helpful participations and cooperation, so that this research can be carried out well.

\section{REFERENCES}

Artayasa, I. P., Susilo, H., Lestari, U., \& Indriwati, S. E. (2017). The effectiveness of the three levels of inquiry in improving teacher training students' science process skills. Journal of Baltic Science Education, 16(6), 908-919. Retrieved from http://oaji.net/articles/2017/987-1513 971002.pdf

Bigbee, A., Curtiss, J., Litwin, L., \& Harkin, M. (2010). Multiagency C2 experiment lifecycles: The collaborative experimentation environment as a case study. The International C2 Journal, 4(3), 1-24. Retrieved from https://www.mitre.org/ sites/default/files/pdf/09_4330.pdf

Blankenburg, J. S., Höffler, T. N., \& Parchmann, I. (2016). Fostering today what is needed tomorrow: Investigating students' interest in science. Science Education, 100(2), 364-391. https://doi. org/10.1002/sce.21204

Brooks-Young, S. (2007). Digital-Age Literacy for Teachers: Applying Technology Standards in Everyday Practice. USA: International Society for Technology in Education.

Chiappetta, E. L., \& Koballa, T. R. (2010). Thoughts and actions of beginning science teachers. In Science Instruction in the Middle and Secondary Schools: Developing Fundamental Knowledge and Skills (Seventh Ed, pp. 1-13). Houston: Pearson.

Dimopoulos, D. I., Paraskevopoulos, S., \& Pantis, J. D. (2009). Planning educational activities and teaching strategies on constructing a conservation educational module. International Journal of Environmental and Science Education, 4(4), 351-364. Retrieved from https:// files.eric.ed.gov/fulltext/EJ884402.pdf

Durib, M. J. (2014). Challenges of globalization to school curricula from the point of view of faculty members with suggestions of how to deal with it. Procedia - Social and Behavioral Sciences, 112(Iceepsy 2013), 1196-1206. https://doi.org/10.1016/j.sbsp ro.2014.01.1284

Durmaz, H., \& Mutlu, S. (2017). The effect of an instructional intervention on elementary students' science process skills. Journal of Educational Research, 110(4), 433-445. https://doi.org/10.1080 /00220671.2015.1118003

Ergul, R., Simsekli, Y., Calis, S., Ozdilek, Z., Gocmencelebi, S., \& Sanli, M. (2011). The effects of inquiry-based science teaching on elementary school students' science process skills and science attitudes. Bulgarian Journal of Science and Education Policy (BJSEP), Volume, 5(1), 49-68. Retrieved from http://seearticles.ceon.rs/data/pdf/1313-1958/2011/ 1313-19581101048E.pdf

Fiksl, M., Flogie, A., \& Aberšek, B. (2017). Innovative teaching/ learning methods to improve science, technology and engineering classroom climate and interest. Journal of Baltic Science Education, 16(6), 1009-1020.

Goryakin, Y., Lobstein, T., James, W. P. T., \& Suhrcke, M. (2015). The impact of economic, political and social globalization on overweight and obesity in the 56 low and middle income countries. Social Science and Medicine, 133, 67-76. https://doi.org/10.1016/j.socscimed.2015.0 3.030

Hobson, A. (2012). Teaching relevant science for scientific literacy. Journal of College Science Teaching, 30(4), 238-243. Retrieved from http://citeseerx.ist.psu. edu/viewdoc/download?doi=10.1.1.585.88 $67 \&$ rep $=$ rep $1 \&$ type $=$ pdf

Hoferichter, F., Raufelder, D., \& Eid, M. (2015). Socio-motivational moderatorstwo sides of the same coin? Testing the potential buffering role of sociomotivational relationships on achievement drive and test anxiety among German and Canadian secondary school students. Frontiers in Psychology, 6(OCT), 1-13. https://doi.org/10.3389/fpsyg.2015.01675

Holbrook, J., \& Rannikmae, M. (2009). The meaning of scientific literacy. International Journal of Environmental \& Science Education, 4(3), 275-288. Retrieved from https://files.eric.ed.gov /fulltext/EJ884397.pdf

Husamah, H., Fatmawati, D., \& Setyawan, D. (2018). OIDDE learning model: Improving higher order thinking skills of biology teacher candidates. International Journal of Instruction, 11(2). https://doi. 
org/10.12973/iji.2018.11217a

Ismaili, M. (2000). The effectiveness of the task-based learning in developing students' speaking skills in academic settings on the EFL classroom-A study conducted at South East European University (SEEU). In 1st Albania International Conference on Education (AICE) (pp. 291-299).

J. Brame, C., \& Biel, R. (2015). Group work: Using cooperative learning groups effectively. Retrieved from http://cft. vanderbilt.edu/guides-sub-pages/settingup-and-facilitating-group-work-usingcooperative-learning-groups-effectively/

Jonnalagedda, S. (2011). Revenue generation in the information era: Opportunities and challenges. IIMB Management Review, 23(1), 51-63. https://doi.org/10.1016/j. iimb.2011.01.001

Kalolo, J. F. (2014). Improving the quality of science education in Tanzania junior secondary schools: the stakeholders' perspectives, issues, and promising practices. Victoria University of Wellington. https://doi.org/10.1017/CBO9 781107415324.004

Martín, E., Pozo, J. I., Mateos, M., Martín, A., \& del Puy Pérez Echeverria, M. (2014). Infant, primary and secondary teachers' conceptions of learning and teaching and their relation to educational variables. Revista Latinoamericana de Psicología, 46(1-3), 211-221. https://doi.org/10.1016 /S0120-0534(14)70024-X

O'Daniel, M., \& Rosenstein, A. H. (2008). Professional communication and team collaboration. In R. G. Hughes (Ed.), Patient safety and quality: An evidencebased handbook for nurses. Retrieved from https://www.ncbi.nlm.nih.gov/books /NBK2637/

Oscarsson, M., Jidesjö, A., Strömdahl, H., \& Karlsson, K.-G. (2012). Science in society or science in school: Swedish secondary school science teachers' beliefs about science and science lessons in comparison with what their students want to learn. Nordic Studies in Science Education, 5(1), 18. https://doi.org/10.5617/nordina.280

Özgelen, S. (2012). Students' science process skills within a cognitive domain framework. Eurasia Journal of Mathematics, Science and Technology Education. https://doi.org/10.12973/eura sia.2012.846a

PISA (Programme for International Student Assessment). (2015). Pisa results in focus. Retrieved from https://www.oecd.org/ pisa/pisa-2015-results-in-focus.pdf

Prasasti, P. A. T. (2017). Efektivitas scientific approach with guided experiment pada pembelajaran IPA untuk memberdayakan keterampilan proses sains siswa sekolah dasar. Profesi Pendidikan Dasar, 4(1), 19-26. Retrieved from journals.ums.ac.id/ index.php/ppd/article/download/3623/344 6

Pukdeewut, S., Chantarasombat, C., \& Satapornwong, P. (2013). Creative thinking development program for learning activity management of secondary school teachers. International Education Studies, 6(12). https://doi.org/ 10.5539/ies.v6n12p82

Septiani, A., \& Rustaman, N. Y. (2017). Implementation of performance assessment in STEM (Science, Technology, Engineering, Mathematics) Education to detect science process skill. Journal of Physics: Conference Series, 812(1), 012052. https://doi.org/10.1088/1742-659 6/812/1/012052

Yörük, N., Morgil, I., \& Seçken, N. (2010). The effects of science, technology, society, environment (STSE) interactions on teaching chemistry. Natural Science, 02(12), 1417-1424. https://doi.org/10.42 36/ns.2010.212173 